\title{
Reflections from a Summer of Relaxation
}

\author{
Douglas McDougall $\mathbb{D}$
}

Accepted: 2 September 2020 /Published online: 10 September 2020

(C) Ontario Institute for Studies in Education (OISE) 2020

As I write this editorial on the back deck of my house, I reflect on the six months that COVID-19 has affected our social and educational life. There are currently many discussions about how to safely open our schools and universities so that we can continue to learn as a community. Hopefully, you also have more time to read what we have learned about science, mathematics, and technology education and that the articles in this issue will further your understanding of teaching and learning in these fields.

You may have noticed that there has been a major expansion in the number of articles published in CJSMTE. Our goal is to bring you approximately 12 articles per issue. We have expanded the range of topics and the types of manuscripts in our journal. For example, in this issue, you will find commentaries by our two mathematics education editors. In the first commentary, Professor Egan Chernoff, University of Saskatchewan, our mathematics editor for English-language manuscripts, describes his journey in becoming an editor in the journal (Chernoff, 2020). He begins with a camping trip experience and enlightens the reader with his journey as an editor with numerous connections to CJSMTE and to the field of mathematics education. Egan takes us on a humorous and insightful excursion as he develops into an editor through a change in publishers and editors-in-chief. I am very happy that he is still with us!

Caroline Lajoie, the mathematics editor for French-language manuscripts, writes a second commentary about the experiences of being a mathematics editor. In this French-language article, she provides the reader with some thoughts about the journal and what she has been doing to give back to the academic community through her work as an editor (Lajoie, 2020). She reviewed the first 20 years of mathematics articles to get a sense of the role of diversity in CJSMTE. She discovered four different forms: the language of publication, their geographical origin, their scientific field of reference, and the current theory(ies) from which they come. She presents several themes and their corresponding authors in her commentary.

Reflecting on these two commentaries, I thought about my own journey in becoming the Editor-in-Chief of this journal. In the Fall of 2018, then Editor-in-Chief John Wallace had announced his retirement from the journal. There was a posting at the Department of Curriculum, Teaching and Learning (my home department) inviting applications to fulfill the role of CJSMTE's Editor-in-Chief (EIC). I was six months from the end of my time as Associate Dean, Programs, and I wanted to make a contribution to the Centre for Science, Mathematics and Technology Education, where I was once Director before my long leadership

D. McDougall $(\bowtie)$

Ontario Institute for Studies in Education, University of Toronto, 252 Bloor Street West, Toronto, Ontario M5S 1V6, Canada e-mail: doug.mcdougall@utoronto.ca 
journey within the department and then in the Dean's Office. I applied and was appointed the Editor-inChief in January 2019.

We had moved to Springer the previous year and so we were in the midst of a publisher change. Nadia Qureshi, the CJSMTE editorial assistant, was helping to make the transition and was a wonderful help to me as I started as EIC. John Wallace was also very supportive in mentoring me into the new role as he shared his 11 years of experience as CJSMTE's EIC. Issue 19.1 was published and 19.2 was almost completed when I started. Therefore, issue 19.3 was the first issue that I followed from start to finish. However, it was not completely start to finish as many of the manuscripts were already through most of the review cycle and had already been accepted by our editors from the journal.

I inherited an incredible team of editors from John. I called each of them to ask them to stay on with CJSMTE and to assist me in learning about the role. They all agreed to stay and what a joyful day for me that was! Over the next few months, I asked Professor Jim Hewitt, OISE, to join the team of editors as the Technology Editor and he agreed.

The team was now set, and we met in June 2019 face-to-face to discuss the journal and talk about future plans. We also learned that Springer had expected that we increase the number of manuscripts published in each issue from six to twelve. We certainly had our work cut out for us. We prepared a communications plan with our newly formed student committee. We started to attend conferences regularly to talk about the journal and distributed flyers. We started Twitter and LinkedIn accounts and posted updates at least five times per week. We are now interviewing authors of articles in the journal and posting them on our YouTube account.

In September 2019, Sofia Ferreyro-Mazieres, another Ph.D. student from OISE, filled in for Nadia's role as she took a one-year maternity leave. Sofia brought a wealth of organizational skills and knowledge and was the Communications Director of the journal. She helped to organize our October 2019 and May 2020 editors meeting and prepare issues 19.4 through 20.3. As she transitions Nadia back into the role, I would like to publicly thank Sofia for stepping into the role over the past year.

This issue continues to celebrate our 20th year and begins our journey to expand the types of manuscripts accepted to the journal. We have two commentaries (from the Mathematics Education editors), nine articles, and a book review. We look forward to receiving additional manuscripts that will expand the types of articles that we publish and add to the range of topics that we have started to see in CJSMTE.

In this issue, there are a couple of articles that investigate teacher noticing. Shin (2020) explored the noticing of students' reasoning about mean and variability by prospective secondary mathematics teachers. The participants analyzed student's written answers to statistics problems based on two levels within the statistics curriculum. The prospective teachers were challenged to interpret the student's understanding of variability. Their noticing skills ranged between no different levels of reasoning to recognizing different developmental levels. In another article, Styers et al. (2020) investigated in-service teachers' professional noticing of slope. They describe the diversity of teacher interpretations. As presented in both articles, there was a noticed lack of diversity in teacher noticing.

There were three articles that focused on reasoning. Passaro (2020) investigated effective reasoning by secondary school students. The article describes the construction of the concept of function through thirteen examples of reasoning. The author found evidence of the importance of good questioning technique and a description of the students' discourse on quantities. In another article, George (2020) explored postsecondary mathematics courses in the Caribbean. She examined gendered participation in post-secondary school mathematics courses over a five-year period. This study used the Caribbean Advanced Proficiency Examination (CAPE) examinations results to determine candidates' course selection and performance. George (2020) found that there was a significant difference in the overall performance by gender with females outperforming their male peers. Hwang et al. (2020) look at reasoning practices in science and mathematics from an elementary school perspective. They found positive relationships among science reasoning, mathematics reasoning, and mathematics applying. They call for a shift in the focus of 
interdisciplinary efforts to emphasize cognitive practices in learning mathematics and science at the elementary school level.

The Franz-Odendaal et al. (2020) article continues to explore the theme of gender by investigating the attitudes of boys and girls in STEM-based careers in Nova Scotia. The research also compared the responses of girls who attended a week-long intensive Science summer camp with those of girls who did not attend the summer camp. Significantly more girls attending the summer camp indicated that they would like to pursue STEM-based careers. The author suggests that enabling girls to interact with STEM professionals and attend a summer camp significantly influences their interest in becoming STEM professionals.

Martinovic and Manizade (2020) investigated the use of dynamic geometric software with 23 secondary school teachers in the USA while they visualized and verified geometric conjectures. She found that the teachers used a combination of four strategies: eyeballing, measurement, constructions, and written statements. The teacher's misconceptions became clearer as they were visualizing conjectures in the software. The use of some shortcuts distorted the solutions, which could be damaging if used during the teaching of geometric conjectures. This research helps us better identify teachers' misconceptions and provides teacher educators with insightful examples of how to help practitioners better understand geometry.

Palomares et al. (2020) investigated estimation problems with university students. The objectives of the research were to statistically identify whether there is a relationship between the solution plan and the content of the estimation task and to investigate the structure of the estimation problem on student success. They found that there was a significant relationship between the proposed solution and the variables of the context of the problem. This research assists us to understand how to promote flexibility in problem solving.

Gerrard (2020) provides a book review on the Coll and Coll (2019) book that focuses on how to learn better outside of school, particularly through visits to museums, science centres, and science field trips. The book helps science teachers bridge these settings with classroom experiences and offers practical strategies that integrate them in and out of class learning experiences. The authors of the book provide extensive links to literature to assist the secondary school science teacher, the pre-service science teacher, and researchers to further their knowledge and understanding of these diverse yet essential learning venues.

\section{References}

Chernoff, E. J. (2020). On the occasion of an anniversary, eh: confessions of a Canadian math ed editor. Canadian Journal of Science, Mathematics and Technology Education, 20(3).

Coll, S. D., \& Coll, R. K. (2019). Enhancing science learning through learning experiences outside school (LEOS): how to learn better during visits to museums, science centres, and science fieldtrips. Leiden: Koninklijke Brill NV, 111.

Franz-Odendaal, T. A., Blotnicky, K. A., \& Joy, P. (2020). Math self-efficacy and the likelihood of pursuing a STEM-based career: a gender-based analysis. Canadian Journal of Science, Mathematics and Technology Education, 20(3). https://doi. org/10.1007/s42330-020-00105-7

George, L. G. (2020). Exploring the M in STEM: post-secondary participation, performance and attrition in mathematics. Canadian Journal of Science, Mathematics and Technology Education, 20(3). https://doi.org/10.1007/s42330-02000095-6

Gerrard, D. (2020). Enhancing science learning through learning experiences outside school (LEOS): a review. Canadian Journal of Science, Mathematics and Technology Education, 20(3). https://doi.org/10.1007/s42330-020-00104-8

Hwang, J., Choi, K. M., \& Hand, B. (2020). Examining domain-general use of reasoning across science and mathematics through performance on standardized assessments. Canadian Journal of Science, Mathematics and Technology Education, 20(3). https://doi.org/10.1007/s42330-020-00108-4

Lajoie, C. (2020). La Revue Canadienne de l'enseignement des sciences, des mathématiques et des technologies: une vitrine de choix pour la diffusion en français de réflexions et recherches en didactique des mathématiques. Canadian Journal of Science, Mathematics and Technology Education, 20(3).

Martinovic, D., \& Manizade, A. G. (2020). Teachers using GeoGebra to visualize and verify conjectures about trapezoids. Canadian Journal of Science, Mathematics and Technology Education, 20(3). https://doi.org/10.1007/s42330-02000103-9 
Palomares, I. F., Segura, C., \& Pla-Castells, M. (2020). Relations entre contexte, situation et schéma de résolution dans des problèmes d'estimation. Canadian Journal of Science, Mathematics and Technology Education, 20(3). https://doi. org/10.1007/s42330-020-00102-w

Passaro, V. (2020). Analyse du déploiement d'un raisonnement covariationnel chez des élèves de 15 à 18 ans. Canadian Journal of Science, Mathematics and Technology Education, 20(3). https://doi.org/10.1007/s42330-020-00101-x

Shin, D. (2020). Prospective mathematics teachers' professional noticing of students' reasoning about mean and variability. Canadian Journal of Science, Mathematics and Technology Education, 20(3). https://doi.org/10.1007/s42330-02000091-w

Styers, J. L., Nagle, C., \& Moore-Russo, D. (2020). Teachers' noticing of students' slope statements: attending and interpreting. Canadian Journal of Science, Mathematics and Technology Education, 20(3). https://doi.org/10.1007/s42330-02000107-5

Publisher's Note Springer Nature remains neutral with regard to jurisdictional claims in published maps and institutional affiliations. 